\title{
シゾフィランの所属リンパ節への影響
}

\author{
加納 有二・角田 浩幸・橋本 循一
}

\section{Effects of Sizofiran on Regional Lymph Nodes in Patients with Head and Neck Cancer}

\author{
Yuji Kano, Hiroyuki Kakuta and Junichi Hashimoto \\ (Teikyo University School of Medicine)
}

The effects of preoperative Sizofiran (SPG) administration on cellular immunity in regional lymph nodes were studied in patients with head and neck cancer and compared with the effect on circulating lymphocytes in peripheral blood. SPG enhanced immunological activities in the regional lymph nodes, as shown by increased cytotoxic activities of the effector cells and increased helper $\mathrm{T}$ lymphocytes and effector cells in the lymph nodes. The tumor-involved lymph nodes treated with SPG contained significantly fewer cytotoxic effector cells with decreased cytotoxic activities and fewer helper T lymphocytes than did uninvolved lymph nodes treated with SPG. The LAK cells derived from the regional lymph node, especially from the tumor-uninvolved nodes which were previouly treated with SPG were thought to have higher cytotoxic activities than those not treated with SPG.

Key words: Sizofiran (SPG), cellular immunity, head and neck cancer, regional lymph node

\section{はじめに}

癌患者の所属リンパ節の免疫能について, 著 者らは所属リンパ節に抗腫瘍免疫能が存在し, その免疫能が末梢血の免疫能とは異なることを 報告した1)2)。また，所属りンパ節の腫瘍浸潤 の有無によって抗腫瘍免疫能の差異が生じてい ることが報告されている3) 5).

近年, 生物反応修飾物質 (BRM, biological response modifier)の一つであるシゾフィラン (SPG, Sizofiran) を用いた免疫療法が行なわれ ている67) が, SPG が頭頸部癌所属リンパ節の 免疫能に及ぼす影響については，十分には解明 されていない。
そこで，SPG を頸部郭清術前に投与して， SPG が頭頸部癌所属りンパ節の細胞性免疫能 に及ぼす影響について，著者らが報告した頭頸 部癌所属リンパ節の細胞性免疫能の検討結果1) を対照にして検討した。所属リンパ節の細胞性 免疫能の検討に当たっては, 摘出した所属リン パ節を転移のないものと転移の認められるもの に分け，リンパ節内のリンパ球の機能分類を行 ない，その機能分類上の特徵を明確にするため に，末梢血の細胞性免疫能と比較して検討した。 方 法

対象は，1988年 5 月より1992年10月までに帝 京大学附属病院耳鼻咽喉科で頸部郭清術を施行 
した，臨床上，所属リンパ節転移を認める stage III または遠隔転移のない stage $\mathrm{N} の$ 頭 頸部癌症例30例とした。 そのうち, シゾフィラ ン (SPG)の投与を行なった症例，すなわち SPG 群症例が，20例である，著者らがすでに 報告した1) SPG の投与を行なわなかった対照 群症例が，10例である。 2 群の内訳は表 1 に示 した.

$\mathrm{SPG}$ 投与は，手術前 5 日と 2 日に $20 \mathrm{mg}$ を 筋注した.

頸部郭清術中に採取した 2 個以上の所属リン パ節を半切して，半切した一方を病理組織検査 に提出し, 残りの $1 / 2$ からリンパ節リンパ球の 細胞性免疫能を測定した。 また，手術直前に採 取した末梢血のリンパ球の細胞性免疫能も測定 した.

細胞性免疫能の検討にあたっては，採取した 所属リンパ節の病理組織検査結果より,リンパ 節転移のない群とリンパ節転移を明らかに認め た群に分けて検討した．著者らが報告した対照 群ではすべてリンパ節転移は認められなかった が，本研究の SPG を投与した群では同一症例 に扣いても,リンパ節内に癌転移のない群(転 移無群：20例) とリンパ節内に癌転移を明らか に認めた群(転移有群：11例)に分けて,リンパ 節リンパ球の細胞性免疫能を検討した（表 1 ）。

測定した細胞性免疫能として，1)CD3， CD 4，CD8，CD4/8 (表 2)，2）2 種類のモノク ローナル抗体を用いた二重染色である two-color 解析による CD57 ・CD16 拈よび CD11b・ $\mathrm{CD} 8$ の測定（表 2），3）リンパ球の免疫活性と して, NK (natural killer) 活性および LAK (lymphokine activated killer) 活性の測定を施行 した.

各機能リンパ球数は，末梢血に打いてはリン パ球数と陽性細胞率をかけて算出した $\left(/ \mathrm{mm}^{3}\right)$. リンパ節の各機能リンパ球数は, フローサイト メトリーのターゲット細胞数に各陽性率をかけ て算出した.

リンパ球の表面抗原の解析は，モノクローナ
ル抗体を用いたフローサイトメトリーを用いて 測定した (FACScan, Becton-Dickinson).

用いたモノクローナル抗体は, single-color では CD3 (Leu4, fluorescein ; FITC, BectonDickinson), CD4 (Leu3a, FITC, Becton-Dickinson), $\mathrm{CD} 8$ (Leu 2a, FITC, Becton-Dickinson) で， two-color では CD57 (Leu7, FITC, Becton-Dickinson), CD16 (Leu11c, phycoerythrin ; PE, Becton-Dickinson), CD11b (Mo1, FITC, Coulter), CD8 (Leu2a, PE, BectonDickinson)である.

測定方法として, single-color 分析では，へ パリン加末梢血にモノクローナル抗体を添加 (室温，15分)したのち溶血(赤血球溶血試薬 2 $\mathrm{ml}$ ，15分)させて，これにPBSを加えて遠心

表 1 頭頸部癌対象症例とその臨床病期

\begin{tabular}{l|c|c|c|c}
\hline \hline & \multicolumn{2}{|c|}{ 対 照 群 } & \multicolumn{2}{|c}{ SPG 群 } \\
\cline { 2 - 5 } & Stage III & Stage N & Stage III & Stage N \\
\hline 喉 頭 & 2 例 & 1 例 & 2 例 & 3 例** \\
上咽頭 & 0 例 & 0 例 & 1 例 & 1 例* \\
中咽頭 & 1 例 & 1 例 & 2 例* & 0 例 \\
下咽頭 & 1 例 & 1 例 & 2 例 & 3 例 \\
口 腔 & 2 例 & 1 例 & 2 例* & 3 例** \\
鼻・副鼻腔 & 0 例 & 0 例 & 0 例 & 1 例
\end{tabular}

（＊印は，転移を認めた症例）

表 2 リンパ球のサブセットと代表する機能

\begin{tabular}{|c|c|}
\hline $\begin{array}{l}\text { モノクローナル抗 } \\
\text { 体との反応性 }\end{array}$ & 機 \\
\hline （single-color 解析） & \\
\hline $\mathrm{CD}^{+}$ & 成熟 $\mathrm{T}$ 細胞 \\
\hline $\mathrm{CD}_{4}^{+}$ & ヘルパー/インデューサーT細胞 \\
\hline $\mathrm{CD}^{+}+$ & $\begin{array}{l}\text { サプレッサー/サイトトキシック } \\
\text { T細胞 }\end{array}$ \\
\hline $\begin{array}{l}\text { CD4/8 } \\
\text { (two-color 解析) }\end{array}$ & $\mathrm{CD} 4 / \mathrm{CD} 8$ 比 \\
\hline $\mathrm{CD} 11 \mathrm{~b}^{+} \mathrm{CD} 8^{+}$ & サプレッサーT細胞 \\
\hline $\mathrm{CD} 11 \mathrm{~b}^{-} \mathrm{CD} 8^{+}$ & サイトトキシック T細胞 \\
\hline $\mathrm{CD} 57^{+} \mathrm{CD} 16^{-}$ & $\mathrm{NK}+(\mathrm{NK}$ 活性弱い) 細胞 \\
\hline $\mathrm{CD} 57^{+} \mathrm{CD} 16^{+}$ & $\mathrm{NK}+\mathrm{NK}$ 活性中程度) 細胞 \\
\hline $\mathrm{CD} 57^{-} \mathrm{CD} 16^{+}$ & NK卅 (NK 活性強度) 細胞 \\
\hline
\end{tabular}


洗浄し (1000 rpm, 5 分), 上清の吸引除去後に $1 \%$ ホルマリン加PBS に再浮遊させてフロー サイトメーター (flow cytometer)にて測定した。 two-color 分析では, single-color 分析と同様 な測定方法を用いたが， ヘパリン加末梢血にモ ノクローナル抗体を添加するときに, FITC (fluorescein) 標識抗体と PE (phycoerythrin) 標 識抗体の両方を同時に添加して測定した.

NK (natural killer) 細胞の 細胞障害活性 (NK 活性) は，比重遠心分離した単核球を生理食塩 水とRPMI-1640 で洗浄したものをェフェク ター細胞とし， ${ }^{51} \mathrm{Cr}$ でラベル $\left(37^{\circ} \mathrm{C} ， 1\right.$ 時間 $) し$ た K-562をターゲット細胞として, triplicate 上でェフェクター細胞とターゲット細胞の比 (ェフェクター：ターゲット)を $20: 1$ にしたと きの反応時間 4 時間の ${ }^{51} \mathrm{Cr}$ 遊離法 $(\gamma$-カウン ター, Pharmacia Ltd.) で求めた (\%細胞障害 活性 $=\{$ 検体遊離 $(\mathrm{cpm})-$ 自然遊離 $(\mathrm{cpm}) /$ 最大 遊離 $(\mathrm{cpm})$ 一自然遊離 $(\mathrm{cpm})\} \times 100)$.

同様に LAK (lymphokine activated killer) 細 胞の細胞障害活性 (LAK 活性) は, 比重遠心分 離した単核球をェフェクター細胞とし， ${ }^{51} \mathrm{Cr}$


ターゲット細胞として，ェフェクター細胞と ターゲット細胞の比(エフェクター：ターゲッ ト)を 20：1にしたときの反応時間 4 時間の ${ }^{51} \mathrm{Cr}$ 遊離法で求めた. LAK (IL-2(一)) 活性は, 分離した単核球をエフェクタ一細胞として直接 に細胞障害活性を測定したもので, LAK (IL-2 $(+)$ ) 活性は, 分離した単核球に rIL-2 (recombinant interleukin 2 , 単核球 $2 \times 10^{6} / \mathrm{ml}$ あたり $100 \mathrm{U} / \mathrm{ml}$ の rIL-2, S-6820, シオノギ) を添加し て培養器中 $\left(37^{\circ} \mathrm{C}, 5 \% \mathrm{CO}_{2}\right)$ で 3 日間培養して LAK 細胞に誘導後, これをェフェクター細胞 として細胞障害活性を測定したものである.

各細胞性免疫能の測定結果の統計的検定は, $\mathrm{t}$-検定を用いた。

\section{結＼cjkstart果}

末梢血とリンパ節に扔いて, $\mathrm{CD} 4^{+}$細胞数 $(へ$ ルパー/インデューサー T細胞数)を図 1 に,
$\mathrm{CD} 4 / \mathrm{CD} 8$ の比を図 2 に, $\mathrm{CD} 11 \mathrm{~b}^{+} \mathrm{CD} 8^{+}$細胞 数(サプレッサーT細胞数)を図 3 に, CD11b$\mathrm{CD} 8^{+}$細胞数 (細胞障害性 $\mathrm{T}$ 細胞数) を図 4 亿, $\mathrm{CD} 57^{+} \mathrm{CD} 16+$ 細胞数で表される中程度の $\mathrm{NK}$

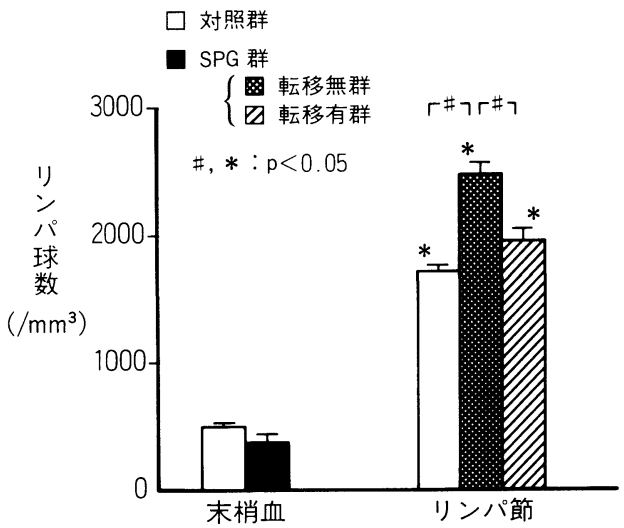

図1末梢血とリンパ節に拈ける CD $4+$ 細 胞数(ヘルパー/インデューサー T細 胞数).

(平均值 + S. E. ). 有意差 $(\mathrm{p}<0.05) ; *$ : 末梢 血対リンパ節, \#：リンパ節に批ける対照群 対 SPG.

縦軸のリンパ球数は, 末梢血においてはリン パ球数と陽性細胞率をかけて算出したもの


細胞数湯性細胞率をかけて算出したもので ある(以下, 図 $3 \sim 5$ の綎軸のリンパ球数も 同様の表示である).

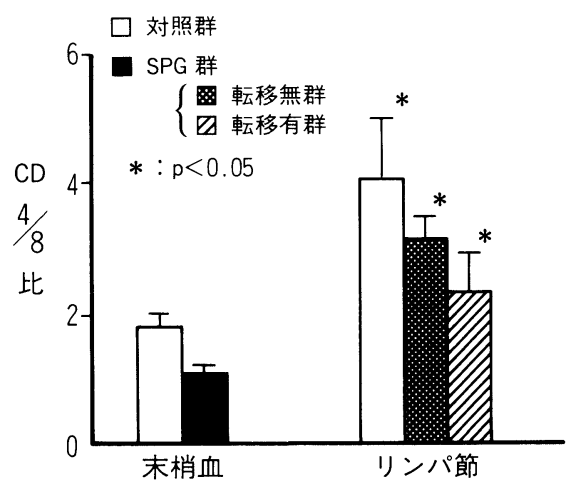

図 2 末梢血とリンパ節に拉ける $\mathrm{CD} 4 / \mathrm{CD} 8$ 比.

(平均値 + S. E. ). 有意差 $(\mathrm{p}<0.05)$; * : 末梢 血対リンパ節. 
活性をもった NK 細胞数を図 5 に, それぞれ 示した。 また，末梢血拉よびリンパ節において， エフェクターとターゲットの比が，20対 1 のと きの NK 活性を図 6 に, 採取した単核球に IL-

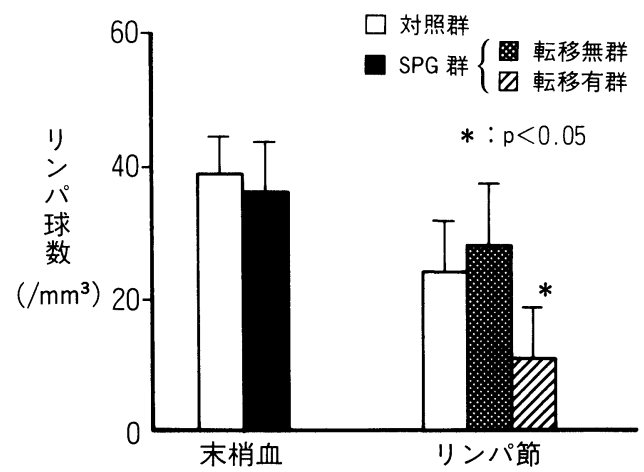

図 3 末梢血とリンパ節に技将る $\mathrm{CD} 11 \mathrm{~b}+\mathrm{CD} 8+$ 細胞数 (サプレッサーT細胞数).

(平均値 + S. E. ). 有意差 $(\mathrm{p}<0.05) ; *$ : 末梢血に おける SPG を投与した群 (SPG 群) 対リンパ節に 扣ける SPG 群のらちリンパ節内に癌転移を認め た群(転移有群).

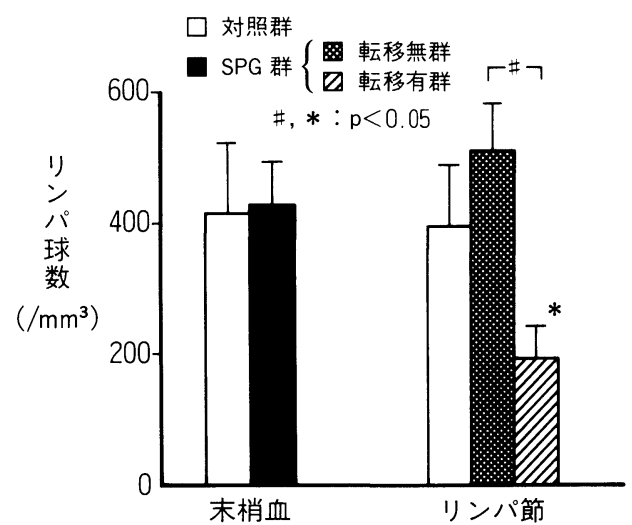

図 4 末梢血とリンパ節に护ける CD $11 b-$ $\mathrm{CD} 8^{+}$細胞数 (細胞障害性 $\mathrm{T}$ 細胞数).

(平均值 + S. E. ). 有意差 $(\mathrm{p}<0.05) ; *$ : 末梢 血に扩ける SPG を投与した群 (SPG 群) 対リ ンパ節に叔ける SPG 群のららリンパ節内に 癌転移を認めた群(転移有群), \# : リンパ節 に打忷る SPG 群のらちリンパ節内に癌転移 のない群(転移無群)対癌転移を認めた群 (転 移有群).
2 を添加しないで直接に LAK 活性を測定した 結果を図 7 に，採取した単核球に IL-2 を添加 して LAK 細胞に誘導後の細胞障害活性を測定 した結果を図 8 に，それぞれ示した。

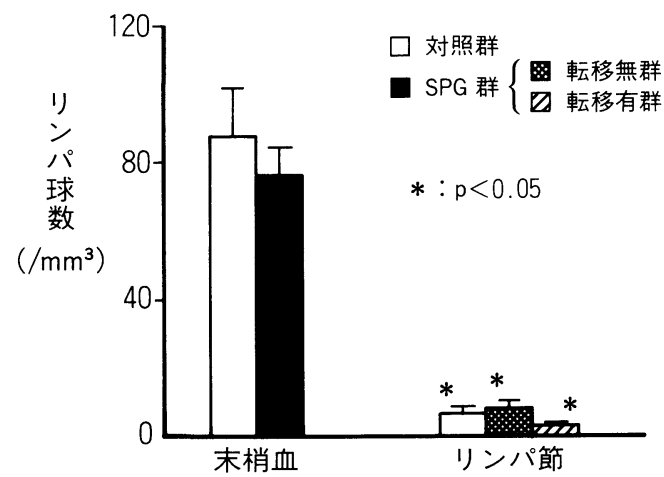

図 5 末梢血とリンパ節における $\mathrm{CD} 57+\mathrm{CD} 16^{+}$ 細胞数 (中程度の NK 活性をもった NK 細 胞数).

(平均值 + S. E.). 有意差 $(\mathrm{p}<0.05) ; *$ : 末梢血対 リンパ節.

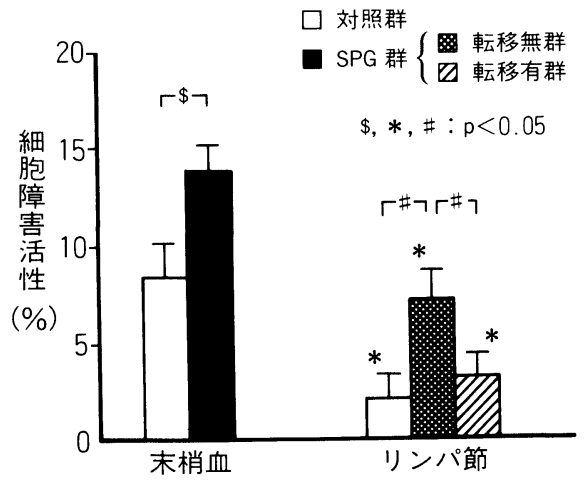

図 6 末梢血とリンパ節に扣ける NK (natural killer) 活性 (エフェクター：ターゲット $=20: 1$ ).

(平均值 $+\mathrm{S} . \mathrm{E}$. ). 有意差 $(\mathrm{p}<0.05) ; *$ : 末梢血 対リンパ節, \#：リンパ節に扎ける対照群対 SPG 群のらちリンパ節内に癌転移のない群(転 移無群)，扣よび SPG 群のらちリンパ節内に 癌転移のない群 (転移無群) 対癌転移を認めた 群(転移有群)，\$：末梢血に打的対照群対 SPG 群. 
末梢血とリンパ節の細胞性免疫能を検討した 結果,

1) 末梢血飞拈いて，シゾフィラン (SPG) を投与した群と SPG を投与しなかった対照群

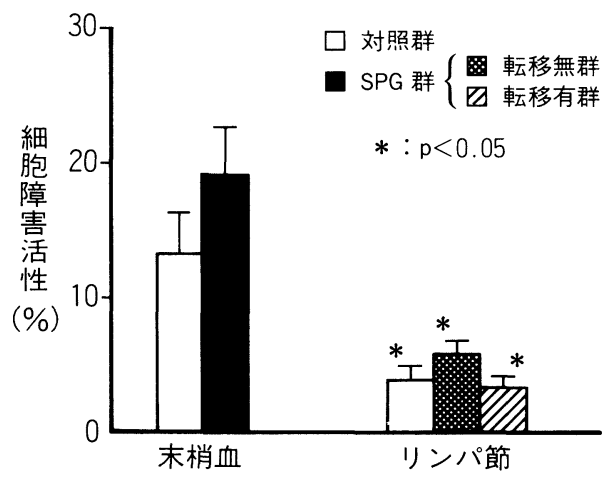

図 7 末梢血とリンパ節に拈ける LAK (IL-2 $(-)$ ) 活性 (lymphokine activated killer 活性).

(平均値 + S. E. ). 有意差 $(\mathrm{p}<0.05) ; *$ : 末梢 血対リンパ節.



図 8 末梢血とリンパ節に拈ける LAK (IL-2 $(+))$ 活性 (lymphokine activated killer 活性).

(平均值 + S. E. ). 有意差 $(\mathrm{p}<0.05) ; *$ : 末梢 血に打ける対照群対リンパ節に打ける対照

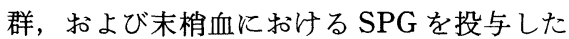
群 (SPG 群) 対リンパ節に执ける SPG 群のう ちリンパ節内に転移を認めた群(転移有群), \# : リンパ節に打ける対照群対 SPG 群 (転移 無群と転移有群), 扎よび SPG 群のらちり ンパ節内に癌転移のない群 (転移無群) 対癌転 移を認めた群(転移有群).
を比較すると，SPGを投与した群では NK 活 性が高值（図 6 )を示した (t-検定， $\mathrm{p}<0.05$ ).

2 ）所属リンパ節では，SPGの術前投与を 行なったか行なわなかったかにかかわらず，末 梢血に比べて, $\mathrm{CD} 57^{+} \mathrm{CD} 16^{+}$細胞数の低值 (図 5 ) と NK 活性(図 6 ) 执よび LAK 活性の低 值 (図 7, 8) と $\mathrm{CD} 4^{+}$細胞数の増多 (図 1 ) 执よ び CD4/8 比の高值 (図 2 ) が認められた ( $\mathrm{t}$-検定, $\mathrm{p}<0.05)$. さらに，SPGを術前投与した群の らちリンパ節内に癌転移を認める所属リンパ節 に执いては，末梢血に比べて， $\mathrm{CD} 11 \mathrm{~b}+\mathrm{CD} 8+$ 細胞数 (図 3 ) と $\mathrm{CD} 11 b^{-} \mathrm{CD} 8^{+}$細胞数 (図 4 ) b 低值を示した $(\mathrm{t}$-検定, $\mathrm{p}<0.05)$.

3 ）SPG を術前投与した群のらち癌転移を 認めない所属リンパ節に括いては, 末梢血と比 較して，IL-2を添加しないで直接に測定した LAK 活性は低值（図 7 )を示した ( $\mathrm{t}$-検定, $\mathrm{p}<$ 0.05). しかし, 採取した単核球に IL-2を添加 して LAK 細胞へ誘導後に測定した細胞障害活 性は，末梢血と同程度の高值（図 8 )を示した。

$4 ）$ 所属リンパ節に拈いて, SPGを投与し た群とSPG を投与しなかった対照群を比較す ると，

ア）SPGを投与した群では，リンパ節内の 癌転移の有無にかかわらず，対照群に比べて， IL-2 を添加して LAK 細胞へ誘導後に測定した 細胞障害活性が高値(図 8 )を示した (t-検定, $\mathrm{p}<0.05)$.

イ）SPGを術前投与した群のらち癌転移を 認めない所属りンパ節に执いては, 対照群に比 べて，IL-2 を添加して LAK 細胞へ誘導後に測 定した細胞障害活性が高値を示した（図８）こと に加えて, さらに $\mathrm{CD} 4^{+}$細胞数の増多(図 1 ) と NK 活性の高値(図 6 ) が認められた (t-検定, $\mathrm{p}<0.05)$.

5 ）SPG を術前投与した所属リンパ節にお いて, リンパ節内の癌転移の有無で比較すると, 癌転移を認める群では, 癌転移を認めない群に 比べて, $\mathrm{CD} 4^{+}$細胞数の減少 (図 1 ), $\mathrm{CD} 11 \mathrm{~b}^{-}$ $\mathrm{CD} 8+$ 細胞数の減少 (図 4), NK 活性の低值 
（図 6 ）および IL-2 を添加してLAK 細胞へ誘 導後に測定した細胞障害活性の低値(図 8 ) が認 められた $(\mathrm{t}-$ 検定, $\mathrm{p}<0.05)$.

所属リンパ節の免疫能は末梢血と異なって掠 り，所属リンパ節では， NK 細胞などの抗腫瘍 性のエフェクタ一系細胞は乏しく，その細胞障 害活性も低值で, $\mathrm{CD} 4^{+}$細胞を中心としたへル パー細胞群が豊富であると考えられた。

シゾフィラン $(\mathrm{SPG})$ 投与が頭頸部癌患者の 所属リンパ節の細胞性免疫能に与える影響を検 討した結果，SPGは頭頸部癌の所属リンパ節 にたいして，LAK 細胞などの抗腫瘍性のエフ ェクター系細胞の細胞障害活性を増強させると ともに，リンパ節に豊富にあるへルパー細胞 $\left(\mathrm{CD} 4^{+}\right.$細胞 $)$数も増加させて, 抗腫瘍性の細胞 性免疫能の賦活効果があることが示された。

また, SPG 投与後の所属リンパ節の抗腫瘍 性の細胞性免疫能は, 所属リンパ節に括ける癌 転移の有無により異なり, 病理標本で明らかに 癌転移を認めるリンパ節では，癌転移を認めな いリンパ節に比べて減弱していることが示され た。

癌所属リンパ節リンパ球を用いて LAK 細胞 を誘導する場合に，ことに癌転移を認めない所 属リンパ節に颃いては，LAK 調製以前にあら かじめ SPG を投与することにより, SPGの投 与をしない場合に比べて，より細胞障害活性の 高い LAK 細胞が誘導できた.

\section{考察}

シゾフィラン $(\mathrm{SPG})$ は，宿主の免疫応答を 介する間接的な抗腫瘍作用を示す8)ことが知ら れている.

1.シゾフィラン $(\mathrm{SPG})$ が癌所属リンパ節 に及ぼす影響.

SPG の投与が，癌所属りンパ節に及ぼす影 響については，婦人科癌を対象にして清水ら ${ }^{9110)}$ が報告しているが，耳鼻咽喉科・頭頸部外科領 域では，現在まで報告がない。

清水ら ${ }^{9) 10)}$ は, SPG が所属リンパ節に及ぼす 影響はリンパ節内の癌転移の程度により異なり,
リンパ濾胞を破壊していない転移リンパ節にお いては SPGの投与により，SPGの投与を行な わず癌転移を認めないリンパ節同様に NK 活 性は低值のままであるが，LAK 活性と IL-2 産生能は高值を示し, Leu 3a 陽性 (Th) 細胞, IL-2 receptor (IL-2R) 陽性細胞, HLA-DR 陽性 細胞が著増したと報告している。本研究に揖い て癌転移を認めた所属リンパ節では, SPGの 投与により， NK 活性は低值のままであったが 誘導後の LAK 活性は高值を示し, 清水らの報 告9110)とよく一致していた.

SPG 投与が頭頸部癌患者の所属リンパ節の 細胞性免疫能に与える影響を検討した結果, SPG は頭頸部癌の所属リンパ節にたいして, LAK 細胞などの抗腫瘍性のエフェクタ一系細 胞の細胞障害活性を増強させるとともに，リン パ節に豊富にあるへルパー細胞 $\left(\mathrm{CD} 4^{+}\right.$細胞 $)$数 も増加させて, 抗腫瘍性の細胞性免疫能と免疫 監視機構の賦活効果があることが示された。 そ こで，頭頸部癌患者に SPG の全身投与を行な らことにより, 所属リンパ節に扣いて抗腫瘍効 果か，あるいは少なくとも癌転移の抑制効果が 得られると考えられた。

2. 所属リンパ節内の癌転移の有無による細 胞性免疫能の相異.

本研究の SPG を投与した所属りンパ節の細 胞性免疫能は, 所属リンパ節の癌転移の有無に より差を認めた。差を認めた測定項目は, $\mathrm{CD} 4^{+}$細胞数, $\mathrm{CD} 11 \mathrm{~b}-\mathrm{CD} 8^{+}$細胞数, $\mathrm{NK}$ 活 性, 誘導後の LAK 活性であり, ともに転移を 認めた群で低下して扣り，SPG 投与後の所属 リンパ節の細胞性免疫能は, 転移を認めた群で は転移を認めなかった群に比べ減弱していた。

癌浸潤を認めるリンパ節の抗腫瘍性の免疫能 は, 癌転移を認めないリンパ節の免疫能に比べ 低下しているとの報告がなされている32 5)。 リ ンパ節への癌浸潤によりすでに抗腫瘍性の免疫 能が低下しているために，SPGを投与してえ られる抗腫瘍性免疫能の賦活効果が，転移を認 めないリンパ節に扣ける SPG による免疫能の 
賦活効果ほどには十分に得られなかったものと 考えられた.SPGを投与してえられる癌転移 を認める所属りンパ節の抗腫瘍性免疫能の賦活 効果をより明確にするには, 癌転移を認める所 属リンパ節の細胞性免疫能を対照にして, SPG を投与した場合の癌転移を認めるリンパ 節の細胞性免疫能と比較して検討することが必 要と思われた。

3. 所属リンパ節リンパ球を用いての抗腫瘍 活性の誘導について.

本研究のリンパ節リンパ球に IL- 2 (interleukin 2)を添加して, LAK (lymphokine activated killer) 細胞誘導後に測定した細胞障害 活性は，SPGを投与した群において，リンパ 節内の癌転移の有無にかかわらず, SPGの投 与を行なわなかった転移を認めないリンパ節の 分析結果である対照群に比べて, 有意な高值を 示した.とくに SPG を投与した群のらち転移 のないリンパ節リンパ球に IL-2 を添加して LAK 細胞誘導後に測定した細胞障害活性は, SPG の投与を行なっていない対照群の末梢血 の IL-2 で誘導した後の LAK 活性と同程度の 高值であった. LAK 細胞の調製以前にあらか じめ生体に SPG を投与することにより, SPG を投与しない場合に比べて，より細胞障害活性 の高い LAK 細胞が誘導できると考えられた.

SPG を投与すると IL-2 で誘導した LAK 活 性が，SPGの投与を行なわない場合よりも有 意な高値を示した理由として，SPGによるマ クロファージの活性化とそれにともなら IL-1 などのリンフォカイン分泌促進によって，もと もと所属リンパ節に豊富なへルパー細胞が増加 ならびに機能増強し, IL-2 産生能と応答性の 亢進とともに各種のリンフォカイン (IL-2, IL-3, I$4, \mathrm{IFN}-\gamma$ など)の産生を増強し, さらに各種の リンフォカインが抗腫瘍性のエフェクタ一前駆 細胞に働きかけ，IL-2 応答能の亢進と SPGの 抗腫瘍効果を担った LAK 前駆細胞が誘導され るものと考えられた。

リンパ節リンパ球由来の LAK 細胞を臨床応
用する場合には，IL-2 による活性化で高い細 胞障害活性が誘導されたとの, Snyderman ら や輿田5) や Rivoltini ら ${ }^{11)}$ の報告もあり，LAK の調製に用いるリンパ節の反応形態や腫瘍浸潤 の有無やその程度が重要なポイントであるとと もに，抗 CD3 抗体刺激の併用のみならず12), LAK 調製以前にあらかじめ行なら担癌生体へ のSPGの投与13114) やそれと併用した腫瘍抗原 感作 (in vivo) ${ }^{15)}$ が，高い細胞障害活性をもつ LAK 細胞を誘導するには有効な手段と考えら れる. SPGのみではなく，その他の BRM も 養子免疫療法への積極的な併用投与が試みられ ている.

\section{まとめ}

シゾフィラン $(\mathrm{SPG})$ 投与が頭頸部癌患者の 所属リンパ節の細胞性免疫能に与える影響を検 討した結果, SPGは頭頸部癌の所属リンパ節 にたいして，LAK 細胞などの抗腫瘍性のェフ ェクター系細胞の細胞障害活性を増強させると ともに, リンパ節に豊富にあるへルパー細胞数 も増加させて, 抗腫瘍性の細胞性免疫能の賦活 効果があることが示された.

また，SPG 投与後の所属りンパ節の抗腫瘍 性の細胞性免疫能は, 所属リンパ節に扣ける癌 転移の有無により異なり, 病理標本で明らかに 癌転移を認めるリンパ節では, 癌転移を認めな いリンパ節に比べて減弱していることが示され た。

癌所属リンパ節リンパ球を用いて LAK 細胞 を誘導する場合に，ことに癌転移を認めない所 属リンパ節に拈いては，LAK 調製以前にあら かじめ SPG を投与することにより，SPG の投 与をしない場合に比べて，より細胞障害活性の 高い LAK 細胞が誘導できた.

稿を終えるにあたり，研究に協力していただいた 科研製薬株式会社に感謝する. 本論文の要旨は, 第 31回日本癌治療学会総会にて発表した. 


\section{引用文献}

1）加納有二, 角田浩幸, 橋本循一: 頭頸部癌所属 リンパ節の細胞性免疫能の検討. 耳鼻臨床 86 : 1653 1659, 1993.

2）加納有二, 角田浩幸, 橋本循一 : 術前シゾフィ ラン $(\mathrm{SPG})$ 投与の所属リンパ節の細胞性免疫 能に及ぼす影響 一頭頸部癌患者に打ける検討 一. BIOTHERAPY 7 : 955 963, 1993.

3) Michel RA, Kesseler DJ, Taylor JMG, et al : Natural killer cell cytotoxicity in the peripheral blood, cervical lymph nodes, and tumor of head and neck cancer patients. Cancer Res 48 : 5017 5022, 1988.

4) Snyderman $\mathrm{CH}, \mathrm{Heo} \mathrm{DS}$, Johnson JT, et al : Functional and phenotypic analysis of lymphocytes in head and neck cancer. Arch Otolaryng $117:$ 899 905, 1991.

5）輿田順一：頭頸部悪性腫瘍患者所属リンパ節リ ンパ球の抗腫瘍活性に関する研究. 日耳鼻 95 : 748 758, 1992.

6）加納有二, 角田浩幸, 千葉恭久, 他 : 放射線療 法症例に対するシゾフィラン (SPG) の免疫学 的効果 一頭頸部癌 III期， $\mathrm{N}$ 期を対照とした検 討一. BIOTHERAPY $7:$ 185 190, 1993.

7）橋本循一, 角田浩幸, 千葉恭久, 他：マウス腹 腔内移植 EL-4 lymphoma に対するインターロ イキン 2 とシン゙フィランの併用効果. BIOTHERAPY $4: 1876 \sim 1884,1990$.

8）野田起一郎, 井上芳樹, 老木正彰: Sizofiran (SPG)の子宮頸癌に対する臨床効果. BIOTHERAPY $4:$ 1379 1389, 1990.

9) Shimizu Y, Chen JT, Hirai $Y$, et al : Augmentation of immune responses of pelvic lymph node lymphocytes in cervical cancer patients by sizofiran. Acta Obst Gyneco Jpn 41 : 2013 2014, 1989.

10）清水敬生, 陳 瑞東, 荷見勝彦, 他: 婦人科癌 に対する Sizofiran (SPG) の効果一免疫増強法 についてー. BIOTHERAPY $4: 1390 \sim 1399$, 1990.

11) Rivoltini L, Bambacorti-Passerini C, Squadrelli-Saraceno $\mathrm{M}$, et al : In vivo interleukin 2induced activation of lymphokine activated killer cells and tumor cytotoxic T-cells in cervical lymph nodes of patients with head and neck tumors. Cancer Res $50: 5551 \sim 5557,1990$.

12) Yoshizawa H, Chang AE and Shu S : Specific adoptive immunotherapy mediated by tumordraining lymph node sequentially activated with anti-CD3 and IL-2. J Immunol $147: 729$ $\sim 737,1991$.

13）橋本循一, 角田浩幸, 加納有二 : シゾフィラン に上る養子免疫療法の抗腫瘍効果增強作用 一EL-4 lymphoma 腹腔内移植マウスに打社る 検討一. BIOTHERAPY $6: 962 \sim 968,1992$.

14）橋本循一, 角田浩幸, 加納有二: シゾフィラン による LAK 細胞の細胞障害活性の増強効果に ついて -in vitroでの検討一. BIOTHERAPY 7 : 1257〜1262, 1993.

15）橋本循一, 角田浩幸, 加納有二 : EL-4 lymphoma 腫瘍抗原感作 (in vivo) と sizofiran (SPG) 前処置による養子免疫療法の抗腫瘍効果増強に ついて. BIOTHERAPY $7: 641 \sim 648,1993$.

$$
\left.\begin{array}{l}
\text { 原稿受付: 平成 } 5 \text { 年 } 8 \text { 月 } 5 \text { 日 } \\
\text { 原稿採択 : 平成 } 5 \text { 年 } 9 \text { 月 } 2 \text { 日 } \\
\text { 別刷請求先 : 加納有二 } \\
\text { 干1 } 173 \text { 東京都板橋区加贺2-11-1 } \\
\text { 帝京大学医学部耳鼾咽喉科学教室 }
\end{array}\right)
$$

